Climate Justice: Contested Discourse and Social Transformation

Eurig Scandrett

Sociology

Queen Margaret University

Musselburgh

EH21 6UU

escandrett@qmu.ac.uk 


\section{Climate Justice: Contested Discourse and Social Transformation}

\section{Introduction}

Climate justice is often described as a framework which links the policies and technologies of tackling climate change with some kind of approach to social justice (human rights, redistribution, impact on the poor etc). This paper argues that in order for climate justice to have integrity, it must be rooted in the material interests of those social groups negatively affected by and engaged in struggles against the hydrocarbon economy. Many such groups do not identify with climate justice but have common cause with climate justice action which is oriented critically against an economic logic of growth and capital accumulation.

Climate justice as a concept has a relatively recent history, moving quickly from social movements and radical NGOs to policy debates. The Mary Robinson Foundation (no date) has taken an authoritative position in seeking to promote a perspective of climate justice which links human rights to development, "safeguarding the rights of the most vulnerable and sharing the burdens and benefits of climate change and its resolution equitably and fairly." As Bond and Dorsey (2010) point out, this interpretation of climate justice, located in a discourse of development policy is one of several that are contested and serve different sets of interests. Whilst providing an important corrective to narratives about climate change which ignore the differential interests of social groups, and thereby providing an approach to climate mitigation and adaptation which is somewhat redistributive, development and human rights tends to promote versions of climate justice that leave unchallenged entrenched vested interests.

Rather than seeking an agreed definition of climate justice, this article argues that the diverse, potentially contradictory and contested meanings and practices which constitute climate justice discourse should provide a source of analysis of the processes of contestation amongst social groups necessary for delivering climate justice. Discourses reflect the material interests of social groups with differential access to the discourse forming process. Because climate justice discourse influences policy, an analysis of such interests will contribute to an understanding of which interests are enhanced and which are neglected, and therefore the likely social distribution of costs and benefits in the implementation of policy. Virtually all interpretations of climate justice seek interventions that protect the poorest and most vulnerable and promote greater equality, or at least do not exacerbate inequality. Climate justice discourse therefore carries greater moral authority when it embeds the material interests of those groups who are currently experiencing the costs of climate change most severely (and also serves to critique the material interests of those who are benefiting). This can only occur through the engagement in discourse production by such groups who are active in challenging these costs, by articulating their collective interests in contestation with the causes of climate change - the hydrocarbon industry and its investors,

Climate justice therefore faces two types of challenge. First, is for climate justice theorists to analyse the material interests which are embedded within the discourse. When advocates of climate justice ignore these material interests, there is a risk of rendering inconceivable, forms of social change which challenge hegemonic groups. Such a discourse therefore serves to prevent the implementation of climate justice.

The second challenge lies in the theoretical and practical barriers involved in building the climate justice movement. A conceptual distinction is made between the Climate Justice 
Movement which emerged from global justice protests and has been at the forefront of shifting discourse from climate change to climate justice, and the climate justice movement which constitutes a broader potential collectivity of communities and social groups engaged in conflict with the hydrocarbon industry. This distinction is more heuristic than empirical, but serves the purpose of addressing the process of developing climate justice discourse. Although the Climate Justice Movement includes many examples of grassroots campaigns and movements of directly affected communities who are challenging climate change (for examples see Klein, 2014), there remains a disconnect between the Movement and many communities challenging the hydrocarbon industry and its owners.

In some respects this is not new, but is rather a similar challenge of alliance building between environmentalist and social justice movements which has been addressed both theoretically and practically for over fifty years (in, for example the Red-Green and ecosocialist literature (Bahro, 1982; Weston, 1986; Gorz, 1987; Pepper, 1993; O'Connor, 1998; Capital \& Class, 2000)). However, in climate justice, the barrier is not just between different types of movement fighting disparate symptoms of a common cause, but additionally faces the problem that climate change constitutes the symptoms of the uncontrolled waste stream of an exploitative hydrocarbon industry which is being resisted throughout its economy. Many movements do not experience 'climate change' directly, but its impacts or else the exploitation processes elsewhere in the political ecology of the industrial process. In which case addressing this challenge requires an understanding of social movement processes and the collective learning which occurs within them. 
As narratives of climate justice find their way into policy discourse, the question of whose interests are served and whose damaged attains greater significance. In Scotland, climate justice policy is framed in terms of the relationship between North and South and the histories of colonialism of and solidarity with the people of the South. The Scottish Government's Climate Justice Fund provides seed funds for development projects in the South (primarily in Malawi, with which Scotland has a strong historical relationship), using public funds to leverage private capital investments into development projects that promote adaptation and resilience to climate change. At the launch of the Fund, the Scottish Government came under criticism from some who were otherwise supporting the initiative, for failing to meet its own ambitious targets for carbon dioxide emission reductions and continuing to support the fossil fuel industry at home. Moreover, the framing of climate justice as an exclusively North-South issue was politically useful for the secessionist Scottish National Party (SNP) government, serving to demonstrate its capacity to intervene progressively in foreign affairs over which it has no formal responsibility, rather than focusing on the domestic policies that it does. This also provided distance between the SNP and the former Labour-led government which adopted official policy on environmental justice (Scandrett, 2010).

The debates about the meaning of climate justice are similar to those concerning environmental justice, although whereas climate justice originates in the narratives of the global justice movement, environmental justice emerged in the context of the local environmental struggles of directly oppressed groups. In the USA, where environmental justice achieved resonance amongst a range of actors from social movements through to policy makers, its origins - and also its moral integrity - lay in African American struggles against racism (Bullard, 1990). This facilitated the adoption of an environmental justice discourse by other groups that could identify with that struggle, and provided the legitimacy to include within the environmental justice movement groups not directly identifying with an environmental justice discourse (Faber and McCarthy, 2002). It is argued here that, for a discourse of climate justice to achieve this same moral integrity it needs to be rooted in the popular struggles of oppressed groups who share an experience of exploitation by the hydrocarbon industry.

Discourses have an ideological function. They serve the interests of social groups differently and are the result of the combination of contributions to the discourse from these groups. As Raymond Williams (1973) demonstrated, a 'corporate' culture derives from the diverse contributions of symbols, meanings and practices of its component social groups, each reflecting their own collective interests. These groups emerge and decline in influence, and their cultural contribution is incorporated or obstructed, in a constant dynamic process of contestation. Aspects of the corporate culture become hegemonic because they reflect the interests of a sufficiently powerful alliance of social groups. This is a complex process of contestation of meanings, but what is crucial about this analysis is that whilst discursive negotiations occur in the domain of ideas and concepts, they nonetheless retain a reflection of the material interests of the social groups from which they have emerged. Thus, what appears to be 'possible' becomes what is compatible with the interests of groups with sufficient influence in the complex of discourses, and options for change which challenge these interests become 'inconceivable'.

Leslie Sklair (2001) analysed the contestation for hegemonic meaning in the discourse of sustainable development demonstrating the shift in class interests reflected in the meaning of sustainable development as the business community attained greater influence. In the USA in the 1980s, the environmental justice movement not only challenged the racially unequal 
distribution of environmental costs, but also sought to challenge the meaning of 'environment' and the practices of environmentalism. Contrary to the dominant environmental discourse of white, educated, middle class environmentalists, the environmental justice movement insisted that the collective experience of African Americans and other racialised groups in the USA be incorporated into an understanding of the environment (Schlosberg, 2002).

The diversity of narratives of climate change and the interests that they reflect has been well documented (Bäckstrand and Lövbrand, 2007; Urry, 2011; Scandrett, et al. 2012; Ytterstad, 2014). Despite the complexities of contestation, discourses of climate change can broadly be allocated to categories of neoliberal, ecological modernising or transformational, which correspond to the dominance of transnational capital, the professional-managerial class and exploited groups respectively. None is completely hegemonic, and struggles for hegemony reflect the interests of groups with differing material interests. The struggle for hegemony within a discourse serves to ensure that emergent practices and policies protect or enhance the interests of hegemonic groups. In other words, in the contestation of meaning in climate change narratives, it is important to ask whose interests are being served in the policies and practices that result, and whose interests are being neglected.

This social process is seldom explicit and mostly un-noticed, but rather serves to manufacture 'common sense' within which the interests of certain groups are taken for granted. Thus, a neoliberal discourse on climate change can only countenance policy options that protect or enhance the interests of the capitalist class - those who profit from business growth; a modernisation discourse presumes the interests of the technical and managerial class who operationalise it; and a transformational discourse is based on the interests of those currently excluded or exploited in the current system, who have the most to gain from changing it.

Some scholars have sought authoritative justification of environmental and climate justice through claims to social justice in political philosophy (Dobson, 1998; Schlosberg, 2009). However this is unlikely to resolve contested meanings since such justice claims are themselves contested, and arguments for justice can justify neoliberal (Nozick, 2013; Saunders, 1995), ecological modernising (Beck et al.,1994; Rawls, 2009) and transformational (Fraser, 1997; Harvey, 1996) approaches. Rather, it is through understanding the socially produced meanings in discourses that makes it possible to discern amongst claims to climate justice, to enhance the interests of those most dispossessed by climate change and the industry that produces it. Analysing this contestation is to seek to make explicit the interests that are embedded within the discourses of climate justice and therefore can find their way into policy, so that what is largely invisible is made a little clearer. In other words, discussions about climate justice are not just about technologies, policies or meanings, but also about material interests that are embedded in these. It is no accident that climate change policies disproportionately benefit the richest and negatively impact on the poorest (Preston et al., 2014) it is a reflection of the balance of interests that were able to influence the policy discourse. A narrative of climate justice which has integrity must be rooted in the interests of the oppressed through their struggles for justice.

One problem with this claim is the disconnect between climate change and the experiences of those who do not experience 'climate injustice' but rather flooding, drought, storms, crop failure, disease etc. Moreover, climate change describes the impact of the waste stream arising from a hydrocarbon economic cycle, whereas most of the directly affected communities, and 
therefore the local struggles, are facing other stages in the same hydrocarbon economy that are not directly connected with the waste stream. For environmentalists there is an obvious connection between climate change and very many local community campaigns against oil pipelines, refineries, power stations, land grabs, oil palm development, opencast coal mining, gas flaring, fracking, methane extraction, incineration etc. but this is not necessarily obvious, or even tactically valuable to the communities trying to protect their local environments. Whilst the roots of environmental justice in the citizen-based anti-toxics struggles allows for a recognition of such struggles in the environmental justice movement, that becomes more difficult for climate justice struggles.

The Climate Justice Movement emerged from the global justice movement which is identified with the 'battle of Seattle' and other protests at international summits of the WTO or G8 etc (Flesher Fominaya, 2014); participation in the World Social Forum (Sen et al, 2004); or globally connected local actions such as Occupy. The Climate Justice Movement formed in 2007 around the UN Conference of Parties (CoP) 13 in Bali. It demonstrated its strength in opposition to CoP 15 in 2009 in Copenhagen, and organised in Cochabamba, Bolivia in 2010 in the World People's Conference on Climate Change and the Rights of Mother Earth. It has continued to organise, for example in Margarita, Venezuela in 2014, to mobilise protests at Conferences of Parties to the UN Framework Convention on Climate Change, and remains central to any discussion of climate justice (Bond and Dorsey, 2010).

This 'organised' Climate Justice Movement, which has mobilised protests and alternative narratives at international conferences, comprises a wide range of actors, from direct action environmentalists, to indigenous peoples, to directly affected communities, grassroots social movements such as La Via Campesina and radical NGOs such as Friends of the Earth International and Third World Network. However, there remain problems of cultural negotiation between this Movement, and the local community struggles within the broader climate justice movement, with their own traditions of dissent. Bond and Dorsey (2010) provide an optimistic analysis of coalitions forming within this broader climate justice movement and include a number of local community-based struggles against coal mining, power stations, incinerators, oil extraction and even large scale hydro-electric dams. The extent to which these diverse struggles, largely in the USA, identify themselves as part of the climate justice movement is not explained. This process of alliance building is far from simple and not always as optimistic as Bond and Dorsey seem to suggest, and this demands an analysis of how climate justice narratives can develop which are rooted in the material interests of those oppressed by the hydrocarbon industry.

In order to analyse the opportunities and difficulties in constructing such climate justice narratives, it is necessary to draw on 'movement-relevant theory' (Bevington and Dixon, 2005) generated by activists and scholars engaged in struggles against hydrocarbon industry, including campaign materials and activist testimony as well as academic literature. Participatory Action Research, often conducted by activists, sometimes through activistorientated educational programmes and published in blogs, reports to NGOs and student dissertations etc, is an important source of analysis of the cultural dynamics in the construction of climate justice discourse.

Scandrett et al. (2013) refer to a number of examples of such discursive negotiations over climate change. A campaign against the extension of Mainshill opencast coal mine in South 
Lanarkshire attracted local resistance from a working class community whose traditions of dissent - the trades unions and the Labour Party - had been largely abandoned since the defeat of the National Union of Miners in 1985. The conflict over the opencast mine also attracted direct action activists who established a Camp for Climate Action at the mine in order to attempt to sabotage the mine development. There had been a long process of relationship building between the activists at the climate camp and the local working class community. In a pamphlet on the campaign, an activist from the climate camp writes.

"In the summer, during The Camp for Climate Action at Mainshill some people snuck out in the night and dismantled the conveyor belt at Glentaggart opencast mine. This was the first pixie action to be reported since the camp had arrived and it provoked an interesting and difficult discussion between campers and the local anti-opencast campaigners. At the camp we were excited by the news of the action and generally pleased that it had happened. But, in a large meeting at the camp some of the locals told us that they were unhappy with this kind of action-that it increased the amount of lorries transporting coal by road in the area, that we'd crossed a line and that if it happened again we wouldn't be seeing them at the camp any more.

"We'd pissed off the very people that we were there to support and it didn't feel good. This was a hard blow to our enthusiasm to push our limits and step-up our tactics to take the fight direct to those waging destruction."

As Scandrett et al. (2013) note: "This conflict is between two cultures of resistance. The traditions, codes of conduct, and nomenclature of the DA [direct action] environmentalists have grown through praxis and debate during actions and camps, on campuses and in squats, online and in the samizdat publications of the movement. This is a culture outside that of conventional working-class community action, which has its own traditions of collective accountability, an intimate knowledge of the local area and workings of opencast mines and a critical respect for legal and state processes from which they had more to lose in the long term." (p. 301)

Conflicts over cultures of resistance to the hydrocarbon economy also emerge in the relationship between directly affected communities and their NGO allies. In recent, currently unpublished research, the author has gathered data on these conflicting narratives where, in the struggle against coal bed methane extraction in Scotland, communities explicitly reject a climate-related narrative as detrimental to their interests because it presumes an a priori opposition to the development, irrespective of the impacts on local public health and economic opportunity. The realities of using Development Planning and environmental licensing regulations and of political lobbying ironically encourage a narrow focus on immediate impacts of the technology and a dismissal of concerns about the climate, and this disconnect is encouraged by developers and their state backers who seek to divide their opposition.

Ó’Donnabháin (2014) analysed a conflict between UK based Earth First! direct action environmental activists and the community of Rossport, Co Mayo, Ireland, the site of a longstanding and acrimonious struggle against the development by Shell of a pipeline to transport gas from offshore extraction for land-based refining. The Irish state has contributed considerable resources to support Shell whilst the local community has received support from aspects of the 'institutional left' in Ireland, largely associated with the Republican movement, and from direct action environmentalists, including many from Britain affiliated to Earth First!. 
The community and its supporters from the left in the Irish urban centres formed an alliance 'Shell to Sea'. The direct action environmentalists were encouraged to be part of the campaign although the ignorance of many of the British activists of the long history of Irish anti-colonial struggle against Britain led to difficult internal conflicts. Material interests from the legacy of colonialism were obscured in the contested construction of discourse.

In his analysis of extracts from pamphlets published by the Earth First!ers, Ó’Donnabháin (2014) highlighted the difficulties in constructing a climate justice discourse through a dialogue between these groups of activist. For the Earth First! activists "... Rossport is the line in the sand. It's the front line in the battle against climate change" (p.28) whilst for the community a more compromised cost-benefit analysis could be countenanced, influenced by their Irish Republican allies. Another Earth First!er writes: "If I'm honest, under pretty much any other circumstances there is no way that I would be actively supporting people who were essentially campaigning for a multinational company to extract and process gas, as long as it happens at sea, and a greater proportion of the profits go to the state." (p.38).

If climate justice is to achieve the integrity of being rooted in the material interests of social groups oppressed by the hydrocarbon economy, how are these challenges to be addressed? Raymond Williams (1989) used the term 'militant particularism' to describe the forms of resistance which particular groups develop to address their own experiences of oppression and which can both empower and set limits to action. Nilsen and Cox (2013) locate militant particularism within what they call a 'social movement process' in which the dialectic between empowerment and limitation generates a collective learning process which deepens political analysis and addresses common causes of diverse struggles.

The experience of a respondent in one of the communities challenging coal bed methane extraction in Scotland describes this process.

"I started off this process believing they [the company] should be an integral part of it. That fits with my [philosophy:] there can be no learning if there is no communication and there can be no resolution if there's no communication. But they just lie, and so that's where it's broken down. You can't talk to somebody if they don't tell the truth. And really the experience with [the company] was them coming to a meeting and then saying something and then the community doing their good research and finding that it's not true. And you know there's only so many times that that can happen and you say, 'you know I don't believe a word that you're saying'...

...Then after the appeal, [the company] suddenly went on the offensive ... they went from [it] being a relatively civil discussion to being quite aggressive ... And that followed through the whole process ... In that situation you are up against someone who is a bully and a liar. So it's very, very difficult to talk to somebody in that situation...

... I've got quite a thick skin but there are times when it was quite hurtful at the public inquiry. They'll do anything - they don't care. ... I'm an 'externality', the community's an 'externality.' You can't talk with somebody if you're not a human being to them - and that goes for all of them...

... after a couple of weeks I went: 'what is the root of this?' ... and I realised that actually the legal system is fucked - deep down I've always known that 'might is right' but what I 
realised after this process is that it is incredibly - you know this conspiracy theory - this is a system that has evolved over time to look like it's doing a job fairly and in fact it's designed to maintain a particular structure. So the penny dropped that the law is an ass. It can only be stopped by another way, but I had to go through all of that process." (unpublished interview transcription 2015)

For Nilsen and Cox (2013), the realisation of the inherent corruption of profit making/cost shifting and the collusion of the legal system - and therefore the limits of struggle within a stateeconomic framework which defends the interests of powerful groups - may be regarded as a step in the social movement process that generates alliances and alternative hegemony. As Nilsen (2010) puts it "social movements from below [are] immanent forces that emerge on the basis of needs and capacities that are simultaneously spawned within and frustrated by a given historical totality - sometimes through submerging everyday struggles, sometimes through making claims on the state within the parameters of an institutionalised social formation, and at other times again through challenging the basal relations of power upon which a social dimension is based" (p. 201).

However, Nilsen and Cox (2013) also remind us that social movement processes are not linear or teleological, but dialectical. At the same time as the social movement process 'from below' is challenging hegemony through praxis, social movements 'from above' also actively engage in discourse generation and negotiation in order to defend and extend their own interests.

Climate justice emerged as a challenge to a climate change discourse which increasingly became restricted by the demands of compatibility with corporate interests with the result that policies incompatible with these interests became inconceivable. This led to disastrous policies such as carbon trading, carbon futures, joint development mechanisms and REDD, which reproduced injustices with limited impact on climate change. The climate justice discourse is now subject to similar contestation between interests. One of the ways in which hegemonic groups are protected is through the obfuscation of interests embedded in discourses, such that ruling interests have the appearance of having universal benefit. The engagement of groups fighting exploitation by the hydrocarbon industry contributes to the exposure of these hegemonic interests. 


\section{Conclusion}

It has been argued that an explicit analysis of interests embedded in climate justice discourse, and incorporating the struggles of groups exploited by the hydrocarbon industry, provides the discourse with moral authority, and contributes to climate policy which is more socially just. However, a discourse with moral authority is inadequate. Incorporating the interests of exploited groups into policy can be understood as part of a social movement process in which the climate justice movement makes claims on the state "within the parameters of an institutionalised social formation". However, as Nilsen (2010) argues that the same movements can, "at other times [challenge] the basal relations of power upon which a social dimension is based" (p. 201).

The Climate Justice Movement clearly expresses a coherent critique of political economy that integrates a range of anti-capitalist analyses with the axioms of indigenous peoples. The report of the Structural Causes Working Group (2010) at the Cochabamba conference diagnoses:

“... capitalist logic places financial gain over people. ... profit and profitability are placed above everything else and the rights to access and the efficiency of basic services for the people are converted into commerce.... Today, "climate change" has become a business for the capitalist system.

Capitalism as a patriarchal system of endless growth is incompatible with life on this finite planet. For the planet, every alternative for life must necessarily be anticapitalist ... The alternatives must lead to a profound transformation of civilization. Without this profound transformation, it will not be possible to continue life on planet Earth."

The ongoing work of exposing the interests embedded in the discourse of climate justice, engaging the groups exploited by the hydrocarbon industry and the praxis of building anticapitalist alternatives are all part of a social movement process which contributes to such a transformation. Harvey (1996) describes discourse as a 'moment' which, in the context of dialectical interaction with others (social relations, material practices, power relations, institution building etc) contributes to 'the locus of change'. In a later elaboration (Harvey, 2010) based on Marx's analysis of the transformation to capitalism he argues that "Social change arises through the dialectical unfolding of relations between seven moments within the body politic of capitalism viewed as an ensemble or assemblage of activities and practices". For scholars engaged in the discourse of climate justice, a reflexive consideration of the material interest embedded in climate justice - and therefore ideological function - is an important component of contributing to such a transformation, as is the pedagogical and dialogical work of engagement with the militant particularism of local struggles against the hydrocarbon industry. 
References

Bäckstrand,, K. and Lövbrand E. (2007). Climate Governance Beyond 2012: Competing Discourses of Green Governmentality, Ecological Modernization and Civic Environmentalism, in Pettenger, M.E. (ed.) The Social Construction of Climate Change: Power, Knowledge, Norms, Discourses. Ashgate, Hampshire UK pp. 123-148

Bahro, R. (1982) Socialism and Survival. Heretic Books, London

Beck, U. Giddens, A and Lash, S. (1994) Reflexive modernisation: Politics, Tradition and Aesthetics in the Modern Social Order. Stanford University Press, Stanford

Bevington, D. and Dixon, C. (2005) Movement-relevant Theory: Rethinking Social Movement Scholarship and Activism. Social Movement Studies 4.3 pp 185-208

Bond, P. and Dorsey, M. K. (2010) 'Anatomies of Environmental Knowledge and Resistance: Diverse Climate Justice Movements and Waning Eco-neoliberalism'. Journal of Australian Political Economy, No. 66, Dec 2010: 286-316

Bullard, R.D. (1990) Dumping in Dixie: Race, Class and Environmental Quality. Westview Press, Boulder CO

Capital \& Class (2000) Environmental Politics: Analysis and Alternatives. Capital \& Class Special Issue: 72

Dobson, A. (1998) Justice and the Environment : Conceptions of Environmental Sustainability and Dimensions of Social Justice. Oxford University Press, Oxford

Faber, D. and McCarthy, D. (2003) "Neo-liberalism, Globalization and the Struggle for Ecological Democracy:Linking Sustainability and Environmental Justice". In J. Agyeman, R. D. Bullard and B. Evans (eds) Just Sustainabilites: Development in an Unequal World. Earthscan, London pp. 38-63

Flesher Fominaya, C. (2014) Social Movements and Globalisation. Palgrave Macmillan, London

Fraser, N. (1997) Justice Interruptus: Critical Reflections on the 'Postsocialist' Condition. Routledge, Abingdon

Gorz, A. (1987) Ecology as Politics Pluto Press, London

Harvey, D. (1996) Justice, Nature and the Geography of Difference. Oxford: Blackwell

Harvey, D. (2010) 'Organizing for the anti-capitalist transition' Interface: a journal for and about social movements Volume 2 (1): 243 - 261 (May 2010)

Klein, N. (2014) This Changes Everything: Capitalism vs. the Climate Penguin, London 
Mary Robinson Foundation (no date) Principles of Climate Justice

http://www.mrfcj.org/about/principles.htmla (accessed 22 May 2015)

Nilsen, A.G. (2010) Dispossession and Resistance in India: The river and the rage. Routledge, Abingdon

Nilsen, A.G. and Cox, L. (2013) What would a Marxist theory of social movements look like? In Barker, C. Cox, L., Krinsky, J. and Nilsen, A.G. (eds) Marxism and Social Movements. BRILL, Leiden pp 63-81

Nozick, R. (2013) Anarchy, State and Utopia. Basic Books, New York

O'Connor, J. (1998) Natural Causes: Essays in Ecological Marxism. Guilford, London

Ó’Donnabháin, St. J. (2014) Ideological Diversity and Alliance Building in Social Movements: the Campaign against Shell in Ireland. Masters Dissertation, National University of Ireland, Maynooth.

Pepper, D. (1993) Eco-socialism: from Deep Ecology to Social Justice. Routledge, Abingdon

Preston, I, Banks, N., Hargreaves, K., Kazmierczak, A., Lucas, K., Mayne, R., Downing, C. and Street, R. (2014) Climate Change and Social Justice: an Evidence Review. Joseph Rowntree Foundation, York

Rawls, J. (2009) A Theory of Justice. Harvard University Press, Harvard

Saunders, P. (1995) Capitalism: A Social Audit. Open University Press, Milton Keynes

Scandrett, E. (2010) 'Environmental justice in Scotland: Incorporation and Conflict'. In Davidson, N., McCafferty, P. and Miller, D. (ed.) NeoLiberal Scotland: Class and Society in a Stateless Nation. Cambridge Scholars Publishing, Cambridge pp 183-201

Scandrett, E. Crowther, J. and McGregor, C. (2012) 'Poverty, protest and popular education: Class Interests in discourses of climate change' in Carvalho, A and Peterson, T.R. (eds). Climate Change Communication and the Transformation of Politics Cambria, London pp. 207-366

Schlosberg, D. (2002) Environmental Justice and the New Pluralism: The Challenge of Difference for Environmentalism. Oxford University Press, Oxford

Schlosberg, D. (2009) Defining Environmental Justice: Theories, Movements, and Nature. Oxford University Press, Oxford

Sen, J., Anand, A., Escobar, A. and Waterman, P. (2004). World Social Forum: Challenging Empires. Viveka Foundation, New Delhi

Sklair, L (2001) The Transnational Capitalist Class. Wiley, Cambridge 
Structural Causes Working Group (2010) Final Conclusions. World People's Conference on Climate Change and the Rights of Mother Earth, Cochabamba, Bolivia

https://pwccc.wordpress.com/2010/04/30/final-conclusions-working-group-1structural-causes/ accessed 22 May 2015

Urry, J (2011) Climate Change and Society. Polity Press, Cambridge

Weston, J (1986) Red and Green: The New Politics of the Environment. Pluto Press, London

Williams, R. (1973) 'Base and Superstructure in Marxist Cultural Theory' New Left Review I/82, 3-16

Williams, R. (1989) Resources of Hope Verso, London

Ytterstad, A. (2014) 'Framing Global Warming: Is That Really the Question? A Realist, Gramscian Critique of the Framing Paradigm in Media and Communication Research' Environmental Communication, 9:1, 1-19 